\title{
Concentration Of Construction Industry In Croatia For The Period 2004-2013
}

\author{
Lana Lovrenčić Butković \\ University of Zagreb, Faculty of Civil \\ Engineering, Department of Construction \\ Management, Zagreb, Croatia \\ llovrencic@grad.hr
}

\author{
Sandra Mišić \\ International Project \\ Management Association (IPMA), \\ Zagreb, Croatia \\ sandra.misic@ipma.ch
}

DOI 10.5592/otmcj.2014.1.9

Research paper

\section{Keywords}

Construction industry, Industrial Concentration, Strategic Alliances
A CONSTANT DECLINE OFTHE CONSTRUCTION INDUSTRYINTHE CROATIAN GDP IS VERY CONCERNING. THE CROATIAN CONSTRUCTION INDUSTRY IS FACING WITH A SIGNIFICANT DECLINE OF THE WHOLE SECTOR. The share of the construction industry within the Croatian GDP was 7.8 percent in 2008. In 2013, that number declined to a devastating 4.4 percent. The concentration ratio shows significant fragmentation. The number of employees shows a negative trend, the number of companies is growing.

A study has shown that Croatian construction industry is strongly fragmented, and has been such even more so after the economic crisis of 2008. Until 2008, the construction industry in Croatia showed constant growth. However, soon after we could notice a decline in employment, concentration ratio of the biggest companies and total revenue decline. Nevertheless, since 2008 there have been strong changes in the sector. Within the context the construction sector within Croatia, this paper mainly focuses on the level in the industry within the past ten years.

From 2004 to 2008, shares of construction in the GDP increased from 4.2 to 7.3 percent. Results from this increase have also spread on the employment, which shows an increase of 61.1 percent. In 2004, there were 6471 registered construction companies with 84642 employees working in the sector. In 2013 there were 11989 companies employing 77129 people. The 2014 construction industry has fallen on its knees and is continuing to fall. Data from 2013 shows the share of construction in the GDP to be 4.2 percent. Industrial concentration is measured by the $4 ; 8 ; 20$ and 30 construction company concentration ratio. The industry is characterized as strongly fragmented: in 2008, 4 biggest companies had a share of 2.95 percent, and in 2012, the share of 4 biggest construction companies held 1.51 percent of total revenue.

The construction industry has a meaningful impact on the Croatian economy, since it is traditionally an important and strong sector. We found that strategic alliances and government incentives can have significant impact on forming the steady ground for a better future in the Croatian construction companies. 


\section{Introduction}

The construction industry has always been closely connected to the social and economic activities of every country. It is a moderator and a motor of the overall economies of countries on their national territory, results of which are expressed through the level and dynamics of growth, and the national product (Medanić, 1997). The importance of Croatian construction for the entire economy is also expressed in all the significant sector indicators. Construction registered a relatively large share in GDP (12.06\% in 1980), while in developed countries the condition is significantly different; these years in Austria (1980 and 1984) produced a share of construction in GDP of $7.7 \%, 7.1 \%$, Germany $7.1 \%$ and $6.7 \%$, and the UK $5.7 \%$ and $5,0 \%$ (Jurčec et al.,1990).

At the beginning of 2001, the share of construction grew in the Croatian GDP and this trend continued during the construction boom, when the Croatian Government adopted many development programmes such as the Subsidised Residential Building Programme (POS) and a four-year plan for the accelerated construction of motorways. During this period, the number of construction companies continuously grew, as well as the value of construction work, number of employees and the the share of construction in the GDP.

However, after the "golden age" in the construction industry (which lasted about seven years), the crisis that began in 2008 in the US reached Croatia, and for the first time in the last seven years it started a slowdown in the construction sector. This was primarily expressed in decreased sales of properties, cuts in infrastructure projects and an increase within the commercial banks of interest rates on housing loans.

Within the context of the Croatian construction sector, this paper mainly focuses on the level of the concentration industry in the past ten years.
Perspective of Croatian construction firms in a low concentration environment will be analyzed and the choice of positional strategies discussed.

The extent of concentration of a particular industry provides useful information on the degree and nature of market competition (Ratnayake 1999, Chiang et al. 2001). As an important indicator of market structure, concentration has an important impact on company performance (Yang et al., 2012). Many resarchers discovered that the construction industry is a low concentrated industry. In Croatia, there has not been a lot of research on the topic of the concentration industry, so we found important to point out the figures of concentration in the past 10 years.

The article proceeds with a brief of Croatian construction sector analysis in the second section, followed by the third that presents the analysis and methodology. The fourth section conveys the main results concerning indicators of concentration. Fifth section presents strategic alliances as a positional strategy to stop the decline we are faceing today. The final, sixth section is offering conclusions, stating that the government should take a leading position in creation of the strategy for bringing construction industry in Croatia back in to life.

\section{Movements of the construction industry in Croatia}

In the past few years, the real estate market was often located in focus of interest of the Croatian public. Public interest increased in consequence of the dynamic increase in real estate prices, as investors created an opportunity for profit. Speeding the process of Croatian accession to the European Union events in the real estate market habr become not only the topic of media interest, but also a sensitive political issue. Specifically, the Stabilisation and Association Agreement provided that at the beginning of 2009, the Republic of Croatia fully liberalize property market, which will allow binding for all individuals who are EU-27 nationals to buy Croatian property without limitations (Lovrinčević, Vizek, 2008). Despite a rich tradition, experience and resources in the business, the construction sector in Croatia has been sinking into a deepening crisis. Consequences are tremendeous, considering the direct effects of construction on the growth of GDP, investment and employment. Analysis of long time series of activities in the construction sector confirms that the role and importance of civil engineering on the overall economic structure of the past decade significantly changed (Buturac, 2013). Great public interest in developments in the real estate market is not proportional with the number and frequency of scientific research on the subject. Moreover, in lack of quality research in public, very superficial analysis are being published, for which the authors used data from a variety of informal and often very biased sources. Analysed is solely the Croatian market, which disables comparison with other countries and the placement of the Croatian real estate market in the global context. Due to the application of biased data and reductionist approach, analysis results in defective courts of the reasons for the increase in real estate prices and the amounts of questionable estimates of future market movements. It does not have to be particularly emphasized that such an analysis can be very devastating. It affects the formation of expectations of citizens and business owners on the status and future trends in the market, based on expectations ultimately forming property prices (Lovrinčević, Vizek, 2008). The year 2013 is marked by continuity of deep crisis in construction activity. It is the crisis of a double-dip during which the strongest decline in activity was recorded in $2010(-15.8 \%)$ and $2012(-11.1 \%)$, the physical volume of construction activity returned to a level accomplished prior to 2002 . In this 
context, a drop of construction activity for $4.1 \%$ in 2013 represents only slowing dynamics fall with intensity of contraction and further classifies construction activities were among the hardest to be hit by the crisis. Thus, the period of 2008 - 2013 in this business resulted with a total loss of 50942 jobs (of which the 2013 counts 7500). The construction activity holds the largest amount of reported obligations before bankruptcy settlements (from 1st October 2010 to 17th February 2014; count 13.3 billion with 9,237 employees), and still this activity leads by insolvency issues (late 2013 year 25.6 $\%$ of all uncommitted basis for payments were related to the construction) (CCE, 2014). (Table 1.) Following data from the Croatian Financial agency, a number of construction companies had a parallel race with a number of employees. From 2009, the number of employment in construction industry is in decline, and number of construction companies records a growth.

\section{Construction industry before 2008}

Periods of greatest economic growth and living standards in Croatia were in the periods between 1870-1913 and 1950-1980. Despite the fact that in the 2oth century Croatia was in two world and one civil war, during the 2oth century it managed to increase its GDP almost nine times, with an average annual growth rate of $2.19 \%$ (Čavrak, Družić et al, 2011). In the early 8os, there was a significant fall in investments in Yugoslavia and Croatia. The causes of downtime forced one to look for an investment in the very active second half of the seventies, when the

\begin{tabular}{|c|c|c|c|c|c|}
\hline \multirow[t]{2}{*}{ Year } & \multirow{2}{*}{$\begin{array}{c}\text { Number of } \\
\text { construction } \\
\text { companies } \\
\text { Total }\end{array}$} & \multicolumn{4}{|c|}{ Number of employees } \\
\hline & & $\begin{array}{c}\text { Small } \\
\text { companies }\end{array}$ & $\begin{array}{c}\text { Middle } \\
\text { companies }\end{array}$ & $\begin{array}{c}\text { Big } \\
\text { companies }\end{array}$ & Total \\
\hline 2004 & 6471 & 34346 & 19253 & 31043 & 84642 \\
\hline 2005 & 7159 & 36293 & 22012 & 31219 & 89524 \\
\hline 2006 & 8084 & 52902 & 19216 & 23131 & 95249 \\
\hline 2007 & 9063 & 58764 & 20791 & 24587 & 104142 \\
\hline 2008 & 11244 & 61049 & 22017 & 24234 & 107300 \\
\hline 2009 & 11350 & 53885 & 20860 & 22366 & 97111 \\
\hline 2010 & 11779 & 49854 & 17982 & 21163 & 88999 \\
\hline 2011 & 11712 & 48022 & 15945 & 18981 & 82948 \\
\hline 2012 & 11295 & 44821 & 15013 & 17576 & 77410 \\
\hline 2013 & 11989 & 47891 & 16385 & 12853 & 77129 \\
\hline
\end{tabular}

Source: Financial agency (Fina) (2014), "RGFI advanced search", available at: http://rgfi. fina.hr/JavnaObjava-web/jsp/prijavaKorisnika.jsp (accessed 2nd April 2014).

Table 1. Trends in construction industry: companies and employment from 2004-2013 investments were well above the real possibilities of society, i.e. the burden of the investment cycle is shifted to a future period. Thus, employment is growing, while the share of construction in GDP decline. Construction was not adjusting to the new market conditions that should seek to inertia and a high degree of solidarity in which large systems (former OOURs) were not adjusted to changes that occurred (Jurčec et al., 1990).

Analysis of long time series of activities in the construction sector confirms that the role and importance of civil engineering in the overall economic structure of the past decade significantly changed. While particular emphasis on two opposing cycles: one before the onset of the recession (until 2008) and the other one upon the occurrence (after 2008). Construction in Croatia in the period from 2000 to 2008 experienced a real "boom". With the increase in the share of construction in GDP (from 4.2 to 7.3 percent), the industry achieved positive effects on employment. Total employment in the construction sector in legal entities in the period 2001 to 2008 increased by 61.1 percent. It also boosted the development of other supporting activities: production in mining and quarrying (gravel and sand), manufacturing (cement, brick, glass, timber, sanitary facilities) and business services (design). In those years, the construction of major infrastructure projects in the field of road construction was one of the main levers of expansion construction in the overall economic structure. Value of construction work in the area of transport infrastructure in the 2008 amounted to about 9.8 billion; in the period from 2000 to 2008 even increased 3.5 times (Buturac, 2013).

From picture 1, we can see that share of construction industry faces trend of constant decline nowdays. That significant change holds a strong position, and needs help in supporting its activities - not in terms of growth, but in terms of survival. 


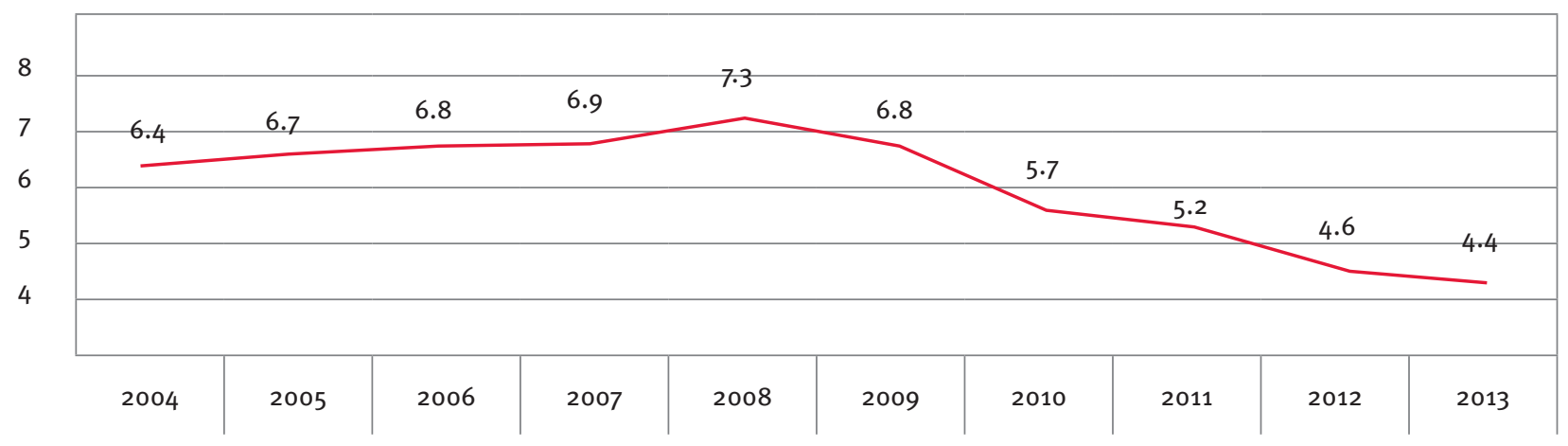

Source: DZS, processing by Croatian Chamber of Economy (2014), „Gospodarska kretanja 29“, available at: http://www.hgk.hr/zk/zadar/gospodarska-kretanja-29-veljaca-2014 (accessed 15 April 2014), pp. 84.

Picture 1. Construction industry in Gross Domestic Product, 2004-2013

\section{Construction industry in Croatia after 2008}

The emergence of the economic crisis mid 2008 stopped the previous longerlasting trend of strong growth in construction. The recession left a deep mark on the overall economic trends. Basic features: rising unemployment, a decline in real wages, the development of consumer pessimism, weakening domestic demand, etc. Compared to other economic activities in Croatia it seems that construction was mostly affected by the recession of 2008 to
May 2013. Civil activity is continuously decreasing. Construction in Croatia in the last few years has been exposed to the consequences of a strong recession. Nevertheless, it still occupies an important place in the Croatian economy. Compared to the Croatian, construction in the EU - 27 showed significantly greater resistance to the recession. Analysis of the latest developments in the construction sector (EU27) showed a trend of gradual recovery activities, which was established in April this year. According to seasonally adjusted data; the central statistical office of the European Union, Eurostat, the volume of construction work in the period from March to July this year increased by 2,9 percent. However, a comparison of data on annual basis shows that in July this year the activity level is still lower than in the same month of the 2012 (1.1 percent). The volume of the construction works in Croatia is continuously declining since the mid of 2008 and the emergence of the global economic crisis. The whole period was marked weakening

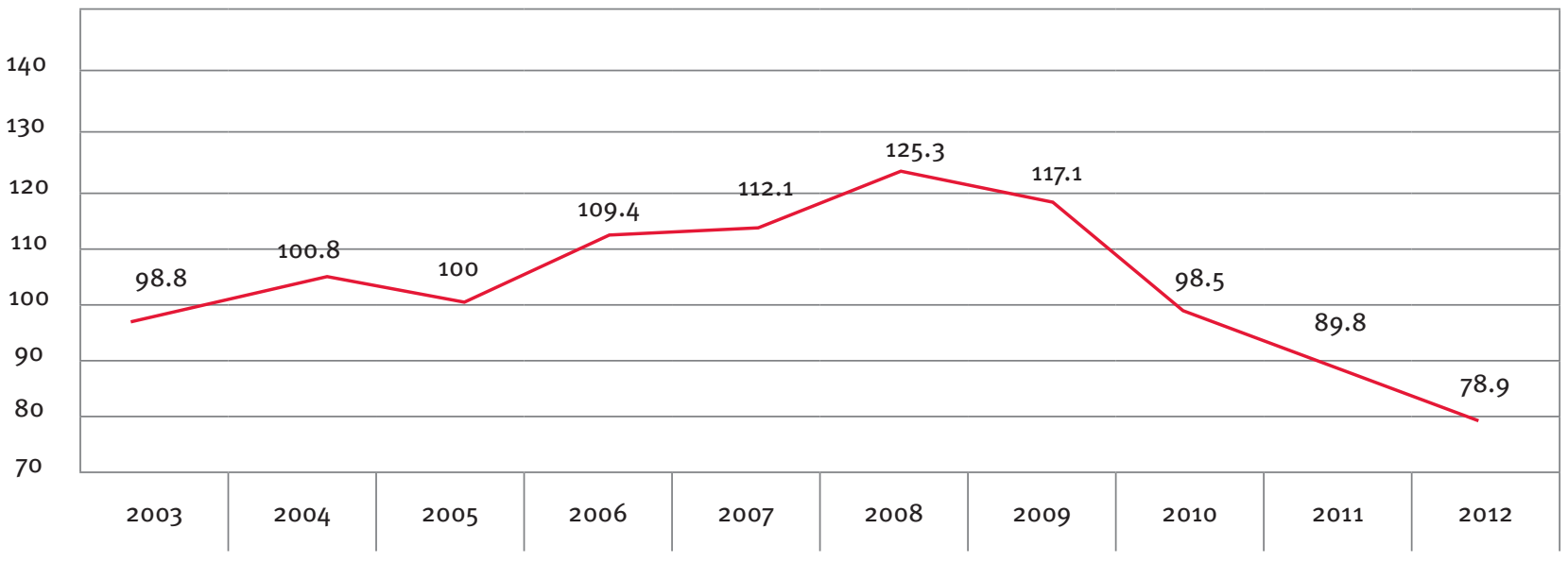

Source: Croatian Bureau of Statistics (2013) „Statistical yearbook 2013 of the Republic of Croatia“, available at: http://www.dzs.hr/Hrv_Eng/ljetopis/2013/sljh2013.pdf (accessed 20.03.2014), pp. 232.

Picture 2. Volume indices of construction works, 2003-2012 
in demand for real estate, a significant slowdown in investment activity and the absence of large civil infrastructure designs (Buturac, 2013).

Difficult situation in the construction of buildings (in 2013 decreased by 12.6 $\%)$ to fourth year recorded consecutive double-digit decline in this segment of construction activity. The main reason for the reduced demand for residential properties is reduced purchasing power of the population (reduced real wages by $1.5 \%$ and reduced levels of home loans 1.9\%). Other reasons include job insecurity and constant sources of revenue (number of employees decreased by $3.3 \%$ ) and uncertainty about the tax treatment of real estate hampers the use of real estate investment as a form of household savings. In addition, there is a substantial market number of completed and unsold apartments, which limits the need to invest in new facilities. It is obvious that the efforts of the country aimed at increasing their investment activities especially investment activities of public enterprises, achieve certain results, but they are still insufficient to reverse the overall trends in the construction industry as a whole (CCE, 2014).

Data on the value of work is based on accounting situations of work carried out on a particular building in the reporting year. In order to avoid double reporting of the value of works, reporting units (legal persons) present only work done by own employees (as direct contract with an investor or as subcontractors of other construction businesses), therefore, no work of their own subcontractors. Value of construction works are presented in current prices and includes the value of work as well as building materials and components, fuel and electricity, the cost of using construction machinery and equipment and other expenses in connection with the construction works. The value of works do not include the value of the works of their own subcontractors, value added tax, purchase of land, land surveying, designing and supervising of (Buturac, 2013). From picture 2. we can see decline of volume indices of construction works from 2008 (the number grew until 2008).

\section{Concentration vs. \\ fragmentation}

Concentration refers to the resources in a market tapped or controlled by a small number of firms. The extent of concentration of a particular industry provides useful information on the degree and nature of market competition (Chiang et al., 2001). The first factor is the concentration of the absolute number of companies that make up one industry. Another factor is the size distribution of firms in the industry, when the size and the proportion of each are defined relative to the entire industry. Both definitional factors must be mutually taken into account when determining whether the industry is concentrated or not. Calculation of total number of companies is not controversial if it is previously well-defined area of the industry. A larger number of companies mainly (but not a rule) associated with unconcentrated industries, and a smaller number of companies linked to a concentrated industry. We can say that the industrial concentration exists when a company or a small group of companies controls a majority share in output of some industry (Tipurić et al., 2002). A concept central to the industrial organization literature is that increased concentration leads to increased market power, while less concentration increases the disciplines on industry pricing. This concept forms the basis of the classical StructureConduct-Performance (S-C-P) approach to industrial organization (Carlton and Perloff, 1999). In response, economists have developed models in which there is substantial feedback between structure, conduct and performance (Jacquemin, 1991). Concentration is a common economic term that many use in an entirely different meaning. The concentration exists when control over most of the total resources achieves a small portion of the total number of units that monitor resource. For economists, the concentration is a common measure of market power in industries. Market power means the degree of control that only one company, or a small number of companies, has over key decisions in any industry. In other words, market power is the ability of companies to increase prices (above marginal costs) without reducing their total sales. The first factor is the concentration of the absolute number of companies that make up one industry. Another factor is the size of the distribution company in the industry when the size and proportion of each defined relative to the entire industry. Both definitional factors must be mutually taken into account when determining whether or not the industry is concentrated. Calculation of the total number of companies is not controversial if the area of the industry is previously welldefined. A larger number of companies are generally (but not a rule) associated with unconcentrated industries, and smaller number of companies are associated with the concentrated industry. We can say that the industrial concentration exists when a company or a small group of companies controls a majority stake in the output of an industry (Tipurić et al., 2002).

Many researchers in the construction industry focus on concentration studies because this labor-intensive industry usually suffers from low concentration and fierce competition (Langford and Male 2001). Disadvantages of high industrial concentration:

1. The inefficiency of resource allocation. Monopolists and oligopolists maximize their profits by restricting output and charge higher prices than competitors in unconcentrated industries. As a result, reduces the welfare of the individual countries.

2. Unprogressivity. Critics say that the 
protected position of competitors in concentrated industry can lead to inefficiency and lethargy due to lack of competition that encourages efficiency and productivity. Next, monopolists and oligopolists often ignore the technological progress, which causes rapid obsolescence of their machinery and equipment, and thus their products.

3. Inequality in income. Industrial concentration contributes to inequality in income because monopolists and oligopolists with the help of entry barriers realize extra profits cascading shareholders and managers, which are generally found in the group with high incomes.

4. The political risk. Because economic power and political power usually go "hand in hand", large corporations can have undue influence on the governments of their countries. This is reflected in legislation and public policy which becomes subordinated to the protection and benefit of large corporations rather than public interest (McConell and Brue, 1996).

The fragmentation of the industry has two different components, namely, the increase in the number of firms and the decrease in their average size. Considering only the increase in the number of firms, we could conclude that the statistical change is the result of a strong growth of the construction market, which has attracted new firms to the industry (increasing the available productive resources). However, (a) the increase in the number of firms has been accompanied by a decrease in their average size. This would not make any sense if the changes in the industry were simply a response to market expansion. Furthermore, (b) the expansion of the market does not necessarily require an increase in the number of firms: the incumbent firms could have grown at the same rate as the market (Stigler, 1951). The fragmentation process can be interpreted as a qualitative change in contractual patterns:
The relationships among the owners of productive resources have been organized less and less by contracts inside the firm (employment relationships) and more by contracts between legally independent firms (market relationships) (Demsetz, 1988).

Chiang et al. (2001) examined the market concentration of four different sectors in the Hong Kong construction industry, and found the building sector was less concentrated than other sectors. McCloughan (2004) found little concentration phenomenon in the British construction market. Zeng et al. (2005) investigated the concentration of the Chinese construction industry using the Lorenz curve and Gini coefficient, and discovered a very low concentration industry.

\section{Analysis of construction industry concentration in Croatia}

For this study, official data on the construction industry was used and analyzed by appropriate statistical methods. The analysis gave a picture of the trend in the construction industry for the past 10 years. Data was taken from FINA, The Institute of Economics and the Croatian Chamber of Economy. Data on total volume indices are based on monthly and quarterly reports on construction (GRAĐ-21/M and GRAĐ-21/3M forms). They are filled in by legal entities and parts thereof, employing 20 or more people, classified into section $\mathrm{F}$ Construction, according to the National Classification of Activities, 2007 version (NN, No. 58/07). Coverage of construction activities is harmonised with section F Construction in the NKD 2007, which includes site preparation (demolition of existing facilities and excavation works), construction building and other constructions (civil engineering works etc.), building installation and completion, and renting construction machinery and equipment with operator. The value of construction works done was presented in current prices and includes the value of work as well as building material and ready-made components and structures used, fuel and electricity, costs of using construction machinery and equipment and other costs connected with construction works (Croatian Bureau of Statistics, 2013).

Within the context of Croatia, this paper has focus on the concentration industry. Under the concept of market, power refers to the ability of companies to influence the price of the product. In this sense, the market might be indirectly expressed by market share, holding that companies with larger market shares have greater impact on prices. Those companies, than, have greater ability to influence the price of the product, they hold more market power. The market power of individual firms is therefore greater if it has a larger market share. Market power can be measured or expressed quantitatively. Various statistical indicators and measures can be used, which are in the statistics called measures of concentration. Measures of concentration show the way of the schedule extensions or other suitable aggregate size of the units string or modalities of statistical variables. They can be divided into absolute measures of concentration and relative measures of concentration. The best-known measure of absolute concentration ratio and the Herfindahl index, and the relative stand out Gini coefficient and associated Lorenz curve. There is yet another indicator that is used as a measure of concentration. It's Lerner index, which is calculated through the relationship of various elements of market conditions (Šošić, 2004).

In Croatia, developments in the construction sector are significant due to the dynamics of the overall economic recovery and labor market trends. Unfavorable trends in the labor market still see no end in sight, at least not in the short period. These estimates of GDP movements and notice of the Government to the need for increasing 
the tax levy does not support the recovery of domestic demand and the development of consumer optimism, which is essential for boosting demand in the real estate market. Although unrealized, prior notice of the introduction of property tax as well as the introduction of the tax on first home purchases have further contributed to the development of insecurity and declining demand in the property market. In the first half of this year, the real estate market was characterized by falling prices where construction companies in the insolvency settlement began to sell unsold flats at a much lower price than before the recession began. Optimistic expectations about the positive effects of Croatian accession to the European Union to improve the overall investment climate, including those in the construction sector, have not been realized. In addition, looking aside the real estate market, joining the European Union has not produced a significant change in real estate prices (Buturac, 2013). According to projections, the European Commission by the end of the 2013 and 2014 expected to be extremely slow economic recovery (European Commission, 2013). This could lead to a weakening demand abroad and lower inflows of foreign investment in Croatia that could be felt in the construction sector, primarily in the real estate market. Also, slow economic growth in Croatia could lead to a further decline in real estate prices which is primarily due to the high income elasticity of real estate prices (Lovrinčević i Vizek, 2008).

\section{Indicators of shares of construction industry in Croatia}

Concentration ratio shows the proportion of largest participants in the overall market, which is being observed. This is the simplest and most widely used measure of concentration (Šošić, 2004). One of the leading theorists of industrial organization, Joe S. Bain, calculated the share of the 50 largest

$$
\mathrm{Cr}=\frac{\mathrm{X}_{1}+\mathrm{X}_{2}+\ldots+\mathrm{Xr}}{\sum_{i=1}^{N} \mathrm{X}_{i}}, \mathrm{X}_{1} \geq \mathrm{X}_{2} \geq \mathrm{X}_{3} \geq \ldots \geq \mathrm{XN}
$$

Source: Tipurić, D., Kolaković, M. i Dumičić, K. (2002),

"Istraživanje promjena u koncentraciji hrvatske bankarske industrije 1993.-2000.", Ekonomski pregled, Vol. 56, No. 5-6, pp. 480.

\section{Picture 3. Concentration ratio}

companies (Bain, 1968), and in the UK is commonly calculated as a share of the thirty largest companies in the industry (Tipurić et al., 2002). In this article, indicator for 4, 8, 20 and 30 largest construction companies in Croatia will be calculated. One can see that indicator of shares in construction industry in Croatia show low stage with minor dinamics.

The values of $x i$ of the variable $X$ are arranged by size in descending order, and $\mathrm{N}$ is the number of values, and here the number of construction companies in Croatia. The sum of the values of variables means overall, ie the total value of the numeric variables (here the total revenue) for all statistical units together, and here - for all construction companies in the country. The ratios were obtained as proportions and is usually read multiplied by 100 , or as percentages. To calculate the concentration ratio, primarily therefore is necessary to sort all construction companies in the industry by realized sales (in monetary units) in a given period (usually a year), from the largest to the smallest. For companies, the percentage of their share in the total sales of the industry is usually calculated. The resulting value shows a higher or lower concentration of the industry. The higher the index value, the higher is the concentration of industry. The higher the value means that a smaller number of large companies achieves a substantial part of industrial sales (and vice-versa). The smaller value of the indicator points to the existence of a large number of relatively small companies, ie to the lower industrial concentration. Thus, for example, if the indicator concentration ratio of the four largest companies in the industry $80 \%$, meaning that the industry is highly concentrated then that four companies actually monitor the industry. It is also clear, if the value of this indicator for the industry $10 \%$, meaning that the industry consists of a large number of companies with approximately the same size and has the characteristics of unconcentrated industries (Tipurić et al., 2002).

Indicator of shares from 2008 shows that 4 biggest companies held 2.95 percent of total ravenues. In 2012 share of 4 biggest companies declined to 1.51 percent. Small value of concentration ratio from 2005-2012 points to lower industry concentration in Croatian construction industry.

\section{Perspective of Croatian construction companies}

Analized data in the previous section shows that the construction industry in Croatia has characteriscs of fragmentation. A small number of firms is controlling the market. Number of companies that creates construction industry in Croatia in 2013 is 11989 companies; with 47891 employees in small companies, 16385 employees in middle companies and $12853 \mathrm{inm}$ big companies.

We tought that entering global markets is increasingly becoming a survival strategy for all companies, 


\begin{tabular}{|l|l|l|l|l|}
\hline Year & First 4 & First 8 & First 20 & First 30 \\
\hline 2005 & 1.97 & 3.4 & 5.1 & 6.01 \\
\hline 2006 & 2.25 & 3.77 & 5.76 & 6.86 \\
\hline 2007 & 2.54 & 4.16 & 3.35 & 6.69 \\
\hline 2008 & 2.95 & 4.89 & 7.37 & 8.57 \\
\hline 2009 & 2.46 & 4.25 & 6.77 & 8.14 \\
\hline 2010 & 2.15 & 3.49 & 5.67 & 6.64 \\
\hline 2012 & 1.58 & 2.78 & 4.57 & 5.76 \\
\hline
\end{tabular}

Source: Financial agency (Fina) (2014), "RGFI advanced search", available at: http://rgfi.fina.hr/JavnaObjava-web/jsp/prijavaKorisnika.jsp (accessed 2 April 2014, data given in HRK).

\section{Table 2. Indicators of shares $(\mathrm{Cr})$ of biggest construction companies in Croatia}

especially for construction companies. Croatian construction companies have enough knowledge and experience to implement the most demanding export projects on international market, but they are too small for competing with foreign competitors. Croatian companies do not have long-term chances to fight with competitors on the foreig markets unless they are members of well prepared, organized and managed strategic alliance capable for creation of added value together with wellchosen and complementary partner(s). Entering foreign markets with welldefined business and well thoughtout marketing strategies, together with creating adequate strategic alliance, should be an essential factor in the successful project management of domestic construction companies on the large global market.

Croatian construction companies today are small entities in the global framework and they considerably lag in efficiency with regard to the leading companies in the world. Croatia is becoming part of global market where global corporations are direct competitors to Croatian firms. Since Croatia has become an EU member state, the construction sector has also become an important part of the global economy and there is an increasing need for domestic construction companies to spread their business operations to foreign markets. Croatian company faces two ways: to be acquired by stronger mega-corporations or to become the member of strategic alliances, which are, again, led and managed by mega-corporations (Tipurić and Markulin, 2002).

Croatian construction industry faces many problems, a lack of investments and foreign investors could be the biggest. Foreign investors in Croatia, gathered in the Foreign Investors Council (FIC), identified the reasons for this in their "White Book", a document assessing the Croatian investment climate (White book, 2013). Among the gravest problems, they mentioned legal insecurity, high and inconsistent taxes, parafiscal charges, long-lasting court proceedings and labour legislation. Because of these obstacles, Croatia is under many criteria one of the worst European countries for investment. In the World Bank and International Financial Corporation report" Doing Business 2013: Smarter Regulations for Small and MediumSize Enterprises" about the ease of doing business, Croatia takes 84th place in a total of 185 world countries (Doing Business, 2013).

One of the main directions of future development for the Croatian contruction companies should be turning to foreign markets and achiving strategic alliances with local or foreign partners. In this case, another problem shows - the problem of unwillingness of Croatian contruction companies to create a cluster or strategic alliances in order to increase competitiveness in foreign markets. At the same time, institutional and financial support by Croatian government almost does not exist. Neverthelles, we believe that achieving strategic alliances and trying to enter foreign markets will be a chance for recovering Croatian construction companies.

Spanish construction industry is characterized by increased fragmentatation. Research conducted in Spain found that changes in regulation over the last two decades are related to the decrease in the average size of the firm. Fragmentation, which is also facilitated by the low cost of firm creation in the construction industry, is the consequence (Gonzales et al., 1998). Concentration of the Chinese construction industry is less than that of developed countries and of other industries in China (Yang et al., 2008).

\section{Conclusion}

This paper provides the Croatian construction sector analysis, through concentration on the companies between 2004 and 2013. The study shows the trend in construction industry in a 10-year period, measured by share of Croatian construction 
industry in GDP, total number of employment in construction and total ravenues of 30 biggest construction companies in Croatia. Perspective of Croatian construction firms in a low concentration environment is analyzed and the choice of positional strategies is discussed. Analysis of long time series of activities in the construction sector confirms that the role and importance of civil engineering on the overall economic structure of the past decade significantly changed. With the increase in the share of construction in GDP (from 4.2 to 7.3 percent), the industry achieved positive effects on employment in the period of 2000-2008 (Buturac, 2013). For 2013 share of construction in GDP is at a devastating 4.4 percent. Workplaces are closing; total ravenues of Croatian construction companies are in constant decline. Data analyzed in previous sections shows that Croatian construction is a low concentrated industry. Share of biggest four companies in total ravenue of the construction industry held 1.95 percent in 2012. Collected data was found as important researc limitation. The growth of construction companies from 2004-2013 is followed by a decline in employment. We think that data for furthure research needs to only take in count companies that have construction as their first or second activity. The constant decline of construction industry in Croatia is faceing problems whose impact could produce a negative impact on society as a whole. One of the main directions for future development of the Croatian contruction companies should be turning to foreign markets and achiving strategic alliances with local or foreign partners. Croatian society will have to wake up from its unwillingnes to create a cluster or strategic alliance. With institutional and financial support by the Croatian government, its construction industry could turn this crisis into a chance for recovery.

\section{References}

Bain, J.S. (1968), Industrial Organization, Second Edition. John Wiley \& Sons, Inc. New York, London, Sidney.

Bijela knjiga (2013), available at: http://ficc. $\mathrm{hr} /$ ?action=home\&lang=hr (accessed 11 December 2013.)

Buturac, G. (2013), „Građevinarstvo i nekretnine“, Sektorske analize, Ekonomski Institut Zagreb, Vol. 24, No. 2., pp. 2-20.

Carlton, D., Perloff, J. (1999), Modern Industrial Organization, 3rd Edition, Reading, AddisonWesley, Massachusetts.

Chiang, Y. H., Tang, B. S., Leung, W. Y. (2001), „Market structure of the construction industry in Hong Kong“, Construction Management and Economics, Vol. 19, No. 7 , pp. 675-687.

Clarke-Hill, C. M., Robinson, T. M. and Bailey, J. (1998), „Skills and competence transfers in European retail alliances a comparison between alliances and joint ventures“, European Business Review, Vol. 98, No. 6, pp. $300-310$.

Croatian Bureau of Statistics (2013), „Statistical yearbook 2013 of the Republic of Croatia“, available at: http://www.dzs.hr/Hrv_Eng/ ljetopis/2013/sljh2013.pdf (accessed 20 March 2014).

Croatian Chamber of Economy (2014), „Gospodarska kretanja 29“, available at: http://www.hgk.hr/zk/zadar/gospodarskakretanja-29-veljaca-2014 (accessed 15 April 2014).

Demsetz, H. (1988), Ownership, Control, and the Firm, Basil Blackwell, New York.

Čavrak V., Družić I., Grahovac P. i sur. (2011), Gospodarstvo Hrvatske. Politička Kultura, Zagreb.

Doing Business (2013), „Smarter Regulations for Small and Medium-Size Enterprises retrieved“, available at: http://www. doingbusiness.org/reports/global-reports/ doing-business-2013 (accessed 14 February 2014)

Doz, Y. L., Hamel, G. (1998), Alliance advantage, Harvard Business School Press, Boston.

European Commission (2013), „European Economic Forecast - Spring 2013“, available at: http://ec.europa.eu/economy_finance/ publications/european_economy/2013/ pdf/2013_05_03_stat_annex_en.pdf (accessed 5 April 2014).
Financial agency (Fina) (2014), „RGFI advanced search“, available at: http://rgfi.fina.hr/ JavnaObjava-web/jsp/prijavaKorisnika.jsp (accessed 2 April 2014).

Gonzales, M., Arrunada, B. and Fernandez, A. (1998), Regulation as a Cause of Firm Fragmentation: The Case of the Spanish Construction Industry. International Review of Law and Economics, Vol. 18, pp. 433-450.

Jurčec, Z., Skendrović, V., Đukan, P. (1990), Osnove programa oživljavanja investicijske aktivnosti u SR Hrvatskoj. Građevinski Institut Zagreb, Zagreb.

Langford, D., and Male, S. (2001), Strategic management in construction. Blackwell Science Ltd., London.

Lovrinčević, Ž., Maruška V. (2008), “House price determinant sin the Republic of Croatia and potential effects of housing market liberalization“, Ekonomski pregled, Vol. 59, No. 12 pp. 723-740.

McCloughan, P. (2004), “Construction sector concentration: evidence from Britain" Construction Management and Economics, Vol. 22, No. 9, pp. 979-990.

McConell, C. R., Brue, S. L. (1996), Microeconomics - Principles, Problems and Policies, McGraw-Hill, Inc., New York.

Medanić, B. (1997), Management u graditeljstvu, Sveučilište Josipa Jurja Strossmayera u Osijeku, Sveučilišta u Rijeci, Splitu i Zagrebu, Osijek.

Prashant, K., Harbir, S. and Honward, P. (2000), „Learning and protection of proprietary assets in Strategic Alliances: Building relational capital“, SMJ, Vol. 21, pp. 217 237.

Ratnayake, R. (1999) „Industry concentration and competition: New Zealand experience“, International Journal of Industrial Organization, Vol.17, No. 7, pp. 1041-1057.

Stigler, G. (1951), “The Division of Labour Is Limited by the Extent of the Market,"Journal of Political Journal of Political Economy, Vol. 59, No.3,pp.185-193.

Tipurić, D., Kolaković, M., Dumičić, K. (2003), „Croatian banking industry concentration changes in 1993-2002“, Zbornik Ekonomskog fakulteta u Zagrebu,Vol.1 No. 1, pp. 1-21.

Tipurić, D., Kolaković, M. i Dumičić, K. (2002), “Istraživanje promjena u koncentraciji hrvatske bankarske industrije 1993.- 
2000.“, Ekonomski pregled, Vol. 56, No.

5-6, pp. 470-494.

Tipurić, D., Markulin, G. (2002), „Partnerships, networks, alliances - new strategic opportunities for Croatian firms“, Podravina, Vol. 1 No. 1, pp. 31-44.

Šošić, I. (2004), Primjenjena statistika, Školska knjiga, Zagreb.

Yang, H., Chan, P.C.A., Yeung, J.F.Y., Li, Q.M. (2012), „Concentration Effect on Construction Firms: Tests of Resource Partitioning Theory in Jiangsu Province (China) from 1989 to 2007 “, Journal of Construction Engineering and Management, Vol. 138 No.1, pp. 144-153.

Whipple, J. S., Gentry, J. J. (2000), „A network comparison of alliance motives and achievement“, Journal of business \& industrial marketing, Vol. 15, No. 5, pp. $301-322$. 